\title{
Ensuring Livelihood of Baiga Tribes through Quality Seed Production Programme
}

\author{
Geeta Singh $^{1 *}$, Harish Dixit ${ }^{1}$ and K.S. Yadav ${ }^{2}$ \\ ${ }^{1}$ Krishi Vigyan Kendra, Dindori (M.P.), India \\ ${ }^{2}$ Krishi Vigyan Kendra, Sagar (M.P.), India \\ *Corresponding author
}

\section{Keywords \\ Baiga tribes, Quality seed production programme, Madhya Pradesh \\ Article Info \\ Accepted: \\ 12 June 2019 \\ Available Online: \\ 10 July 2019}

\section{A B S T R A C T}

Madhya Pradesh is pre-dominated by the Tribal population. The differences in the tribal community, spread over in various parts of the state, is clearly seen not only on the basis of their heredity, lifestyle and cultural traditions, but also from their social, economic structure, religious beliefs and their language and speech. Due to the different linguistic, cultural and geographical environment, and its peculiar complications, the diverse tribal world of Madhya Pradesh has been largely cut-off from the mainstream of development. The population of Tribals in Madhya Pradesh is 122.33 lakh constituting $20.27 \%$ of the total population of Madhya Pradesh (603.85 Lakh), according to the 2001 census. There were 46 recognized Scheduled Tribes and three of them have been identified as "Special Primitive Tribal Groups" in the State. The main tribal groups in Madhya Pradesh are Gond, Bhil, Baiga, Korku, Bhadia, Halba, Kaul, Mariya, and Sahariya. Dhar, Jhabua, Mandla and Dindori districts have more than 50 percent tribal population. The Dindori district comes under Northern Hill region of Chattisgarh. Almost entire district is hilly with undulating topography having different types of soil with large number of small size holding below 2.0 ha. Baigachuck area of Dindori District is mostly dominated by the tribal population. The present pilot project designed on livelihood security of Baiga tribals residing at remote places of the district farming in survival oriented system for livelihood. The primary reports of survey indicated that seed was the most required material keeping this in mind. The project was launched so as to create awareness about seed, production of quality seed for continuous availability in years. The K.V.K. Dindori took up this exploratory programme with rainfed sujata wheat variety on field of 350 farmers in the season Rabi 2007-08.

\section{Introduction}

Krishi Vigyan Kendra Dindori comes under Northern Hill Zones of Chattisgarh surrounded by District Jabalpur, Anuppur Shahdol, Umaria and Mandla of M.P. and Khandwa and Bilaspur of Chhattisgarh.
The average rainfall of the district is $1350 \mathrm{~mm}$. Almost entire district is hilly with undulating topography having different types of soil (about 55\% land is stony, sandy gravels and skeletal $35 \%$ is silty clay with high slopes and $15 \%$ is plain has clay soil). Majority of farmers comes under small size of 
holding below 2.0 ha. Most of the rain water is lost as run off due to steep slopes. The irrigated area is only about $3 \%$ of the total cultivated area. The crop production is completely dependent on rainfall. The changes in crop production technique and other allied fields are still at a very slow rate in the district mainly because of poor socioeconomic conditions topographical situation and under developed facilities of transportation and communication.

The Baiga tribes practice shifting cultivation in forest areas. They say they never ploughed the Earth, because it would be like scratching the breast of their Mother, and how could they possibly ask Mother to produce food from the same patch of earth time and time again - she would have become weakened. That's why Baigas used to lived a semi-nomadic life, and practiced Bewar cultivation (slash \& burn) - out of respect, not aggression. Until fairly recently the Baigas practiced 'dahiya' cultivation, that is, slash and burn. Thousands of squire miles of sal forests have been clean destroyed by them in the progress of their dahiya cultivation, the ground being afterwards occupied by dense scrub of low sal species springing from the stumps. The Baigas are courageous woodsman and hunters.

Majority of Baiga respondents had small holding and resided in farm villages. The tribal baiga farmer had been following survival oriented system of Agriculture with integrated approach of farming, hunting and minor forest collections. Their dependence on forest and forest produces is very much which is not eco-friendly and leads to damage and destruction of forest. Kharif was the only crop growing season and fields remained normally fallow during Rabi.

\section{Map of the district}

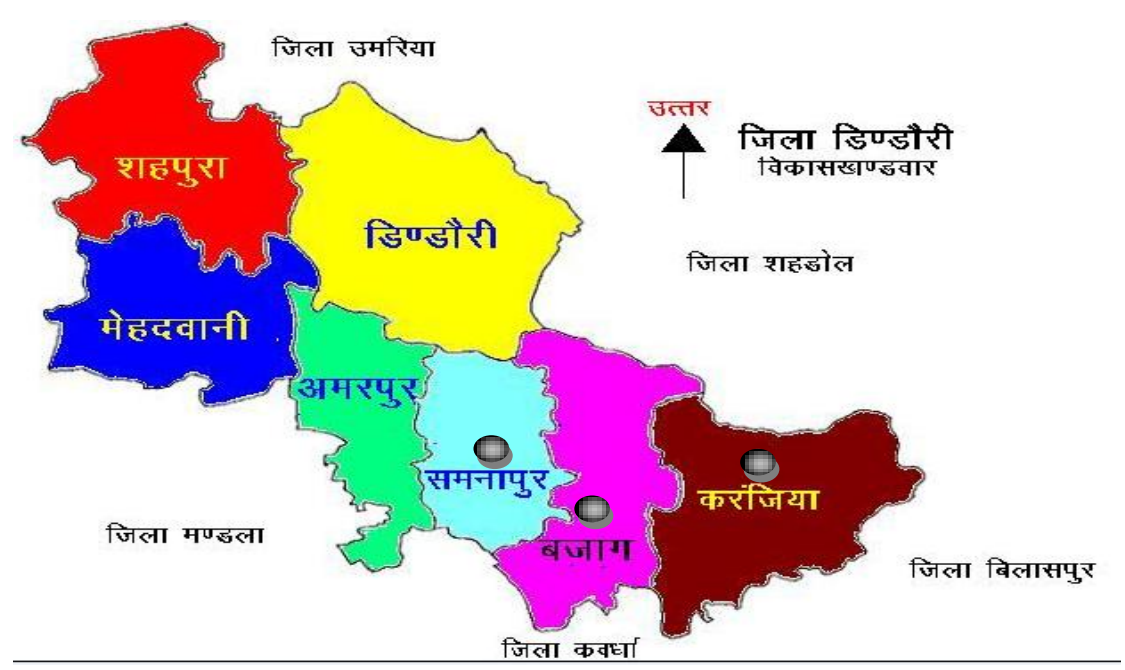

\section{District Statistical Data}

Average Annual Rainfall

Soil Type

Temperature

No. of Blocks

No. of Villages
$1350 \mathrm{~mm}$

$$
\text { :- } \quad \text { Light }-58 \% \text {, Medium- } 27 \% \text {, Heavy- } 15 \%
$$

: $\quad \operatorname{Max} .42^{\circ} \mathrm{C}$, Min. $2^{\circ} \mathrm{C}$

: 7

: $\quad 929$ 


\section{Major Crops of the District}

\begin{tabular}{|l|l|l|l|}
\hline Season & Crop & Area in ha & Productivity $Q / h a$ \\
\hline Kharif & Paddy & 76.1 & 13.74 \\
\cline { 2 - 4 } & Maize & 23.2 & 12.07 \\
\cline { 2 - 4 } & Arhar & 2.5 & 10.00 \\
\cline { 2 - 4 } & Urd & 5.5 & 3.8 \\
\cline { 2 - 4 } & Soybean & 4.9 & 10.17 \\
\cline { 2 - 4 } & Niger & 34.0 & 2.88 \\
\cline { 2 - 4 } & Kodo/Kutki/ Ragi/ Sawa & 43.9 & 4.36 \\
\hline \multirow{7}{*}{ Rabi } & Wheat & 41.3 & 9.21 \\
\cline { 2 - 4 } & Gram & 6.6 & 8.85 \\
\cline { 2 - 4 } & Lentil & 19.6 & 4.80 \\
\cline { 2 - 4 } & Pea & 7.0 & 2.85 \\
\cline { 2 - 4 } & Linseed & 8.0 & 4.55 \\
\cline { 2 - 4 } & Mustard & 22.0 & 4.06 \\
\hline
\end{tabular}

Note: Data represent district as a whole but are a under Rabi in Baiga Chak is negligible.

\section{Fertilizer Consumption $\mathrm{Kg} / \mathrm{ha}$}

$\begin{array}{ll}\mathrm{N} & 8.6 \\ \mathrm{P} & 3.43 \\ \mathrm{~K} & 0.16\end{array}$

\section{Pesticide consumption $\mathrm{Kg} / \mathrm{ha}$}

Fungicide $\quad 0.003$

Insecticide $\quad 0.0132$

Herbicide $\quad 0.0019$

Ensuring the Livelihood Security of tribal farmers through supply of quality seed.

Capacity building including skill improvement of tribal farmers on improved Agricultural technology specially quality seed production and its utilization.

Enhancing the resources for income generation activities and upliftment of socio economic status of the farmers through use of quality seeds.

Enhancing the production and productivity of various crops on tribal farms through quality seed production and its utilization.

\section{Materials and Methods}

The project had been launched in eight villages of three development blocks of Dindori District namely Samnapur, Bajag and Karanjia. The selected villages were Sarai Mal, Majgaon Pipariya, Barga, Podi and Mohati of Samnapur Block Pipariya and Vikrampur of Bajag Block Thadpathra of Kaanjiya Block. The distance of selected villages varies from $35 \mathrm{~km}$ to $90 \mathrm{~km}$ with $3 \mathrm{tm}$ to $18 \mathrm{~km}$ difficult approach. Selection of 350 farmers was done simple random sampling method. Baseline survey of all beneficiaries was done before and after intervention of KVK Project. The impact assessment of the programme was done after three years of project implementation.

\section{Results and Discussion}

The project had been launched in eight villages of three development blocks of Dindori District namely Samnapur, Bajag and Karanjia. The selected villages were Sarai Mal, Majgaon Pipariya, Barga, Podi and Mohati of Samnapur Block Pipariya and 
Vikrampur of Bajag Block Thadpathra of Kaanjiya Block. The distance of selected villages varies from $35 \mathrm{~km}$ to $90 \mathrm{~km}$ with $3 \mathrm{tm}$ to $18 \mathrm{~km}$ difficult approach. Selection of 350 farmers was done simple random sampling method. Baseline survey of all beneficiaries was done before and after intervention of KVK Project. The impact assessment of the programme was done after three years of project implementation.

\section{Annual requirement $\quad 18000.00$ \\ Deficit in Budget $\quad 4500.00$}

Which would be overcome by depts., or sacrificing basic requirements. Observation were recorded prior to and after the demonstration for various factors such as knowledge increase, increase in awareness income levels, employment generation etc. (Table 1)
The data revealed as in the table 2 indicate that out of total 350 beneficiaries $62.85 \%$ beneficiaries had very less awareness about wheat seed production technology and after the intervention of KVK that awareness level reached to $88.57 \%$. This awareness is not only for wheat but similar message has passed for other improved technologies as the scientists used to have interaction on other aspects also during training and visits.

Data in terms of Knowledge level increase. Out of 350 beneficiaries $62.85 \%$ of the tribal farmers had low knowledge level about wheat production technologies which was enhanced upto $78.57 \%$ in the medium category, $7.14 \%$ high level and $14.28 \%$ only remained in low level of knowledge in respect of wheat technology (Table 3).

Table.1 Annual income from different crops and other sources

\begin{tabular}{|l|l|c|}
\hline Season & Name of Crop & Income (Rs/ha) \\
\hline (A)Kharif & Paddy & 1200.00 \\
\hline & Millets & 1000.00 \\
\cline { 2 - 3 } & Niger & 300.00 \\
\cline { 2 - 3 } & Maize & 1000.00 \\
\cline { 2 - 3 } & Arhar & \\
\cline { 2 - 3 } & Moong & $\begin{array}{c}\text { In Small area under recidual } \\
\text { moisture conditions }\end{array}$ \\
\cline { 2 - 3 } & Urud & \\
\hline (B)Rabi & Mustard & 1000.00 \\
\hline & Wheat & 1000.00 \\
\hline (C) & Lentil & 7000.00 \\
\hline (D) & Minor forest products & $\mathbf{1 3 5 0 0 . 0 0}$ \\
\hline (E) & Annual/Live Stock & \\
\hline & Assured income through Rajgar guarantee & \\
\hline
\end{tabular}


Table.2 Distribution of beneficiaries in terms of intervention in awareness

\begin{tabular}{|c|c|c|c|c|c|}
\hline S.No. & $\begin{array}{l}\text { Awareness } \\
\text { Level }\end{array}$ & $\begin{array}{l}\text { No. of Beneficiaries } \\
\text { before K.V.K. } \\
\text { intervention }\end{array}$ & Percentage & $\begin{array}{lr}\text { No. of } & \text { Beneficiaries } \\
\text { after } & \text { K.V.K. } \\
\text { intervention } & \end{array}$ & Percentage \\
\hline 1. & Low & 220 & 62.85 & 00 & 00 \\
\hline 2. & Medium & 128 & 36.57 & 40 & 11.42 \\
\hline 3. & High & 02 & 0.58 & 310 & 88.57 \\
\hline & Total & 350 & 100.00 & 350 & 100.00 \\
\hline
\end{tabular}

Table.3 Distribution of beneficiaries in terms of knowledge level increase

\begin{tabular}{|c|c|c|c|c|c|}
\hline S.No. & Knowledge Level & $\begin{array}{l}\text { No. of Beneficiaries } \\
\text { before } \quad \text { K.V.K. } \\
\text { intervention }\end{array}$ & $\begin{array}{l}\text { Percentag } \\
\text { e }\end{array}$ & $\begin{array}{l}\text { No. of } \\
\text { after } \\
\text { intervention }\end{array}$ & Percentage \\
\hline 1. & Low & 220 & 62.85 & 50 & 14.28 \\
\hline 2. & Medium & 128 & 36.57 & 275 & 78.57 \\
\hline 3. & High & 02 & 0.58 & 25 & 7.14 \\
\hline & Total & 350 & 100.00 & 350 & 100.00 \\
\hline
\end{tabular}

Table.4 Distribution of beneficiaries in terms of employment generation before and after K.V.K. intervention

\begin{tabular}{|c|c|c|c|c|c|}
\hline S.No. & $\begin{array}{l}\text { Available } \\
\text { employment in } \\
\text { days }\end{array}$ & $\begin{array}{l}\text { No. of Beneficiaries } \\
\text { prior to } \\
\text { intervention }\end{array}$ & $\begin{array}{l}\text { Perce } \\
\text { ntage }\end{array}$ & $\begin{array}{lr}\begin{array}{l}\text { No. of } \\
\text { after }\end{array} & \text { Beneficiaries } \\
\text { intervention } & \end{array}$ & Percentage \\
\hline 1. & $\begin{array}{l}\begin{array}{l}\text { Low } \\
\text { days) }\end{array} \\
\text { (Upto } 200\end{array}$ & 330 & 94.28 & 00 & 00 \\
\hline 2. & $\begin{array}{l}\text { Medium (Upto } 300 \\
\text { days) }\end{array}$ & 20 & 5.71 & 338 & 96.57 \\
\hline 3. & $\begin{array}{l}\text { High (Above } 300 \\
\text { days) }\end{array}$ & 00 & 00 & 12 & 3.42 \\
\hline \multicolumn{2}{|r|}{ Total } & 350 & 100 & 350 & 100 \\
\hline
\end{tabular}

Table.5 Distribution of Beneficiaries before \& after KVK intervention in respect of income level

\begin{tabular}{|c|c|c|c|c|c|}
\hline S.No. & $\begin{array}{ll}\text { Income } & \text { Level } \\
\text { Rs./Year } & \end{array}$ & $\begin{array}{l}\text { No. of } \\
\text { Beneficiaries } \\
\text { (Before) }\end{array}$ & Percentage & $\begin{array}{l}\text { No. of } \\
\text { Beneficiaries } \\
\text { (After) }\end{array}$ & Percentage \\
\hline 1. & Upto 12000 & 94 & 26.85 & 10 & 2.85 \\
\hline 2. & Upto 14000 & 240 & 68.27 & 81 & 23.14 \\
\hline \multirow[t]{2}{*}{3.} & $14000 \&$ Above & 16 & 4.57 & 259 & 74.00 \\
\hline & Total & 350 & 100 & 350 & 100 \\
\hline
\end{tabular}


Table.6 Economic impact of the wheat production technology

\begin{tabular}{|l|l|l|l|l|l|l|l|l|l|}
\hline S.No. & \multicolumn{2}{|l|}{$\begin{array}{l}\text { Average } \\
\text { (q/ha) }\end{array}$} & \multicolumn{2}{|l|}{ Yield } & $\begin{array}{l}\text { Average Cost of } \\
\text { Cultivation } \\
\text { (Rs./ha) }\end{array}$ & $\begin{array}{l}\text { Average } \\
\text { Return(Rs./ha) }\end{array}$ & \multicolumn{2}{|c|}{$\begin{array}{l}\text { Gross } \\
\text { Average } \\
\text { Return (Rs./ha) }\end{array}$} \\
\cline { 2 - 10 } & Local & $\begin{array}{l}\text { Dist } \\
\text { Avg }\end{array}$ & Demo & Local & Demo & Local & Demo & Local & Demo \\
\hline 1. & 4.2 & 9.21 & 10.40 & 4620.00 & 7820.00 & 5880.00 & 14560.00 & 1260.00 & 6740.00 \\
\hline
\end{tabular}

Table.7 Incremental change

\begin{tabular}{|c|c|c|c|c|c|c|}
\hline \multirow[t]{2}{*}{ S.No. } & \multirow[t]{2}{*}{$\begin{array}{l}\text { Increase in Yield over } \\
\text { Local Check }(\%)\end{array}$} & \multicolumn{2}{|c|}{ B.C. Ratio } & \multirow{2}{*}{$\begin{array}{l}\text { Expected } \\
\text { Horizontal } \\
\text { spread farmers } \\
\text { over } 350 \text { farms }\end{array}$} & \multicolumn{2}{|c|}{$\begin{array}{l}\text { Cropping } \\
\text { intensity }\end{array}$} \\
\hline & & Local & Demo & & Pre & Post \\
\hline 1. & 147 & 1.27 & 1.86 & 3500 & 100 & 150 \\
\hline
\end{tabular}
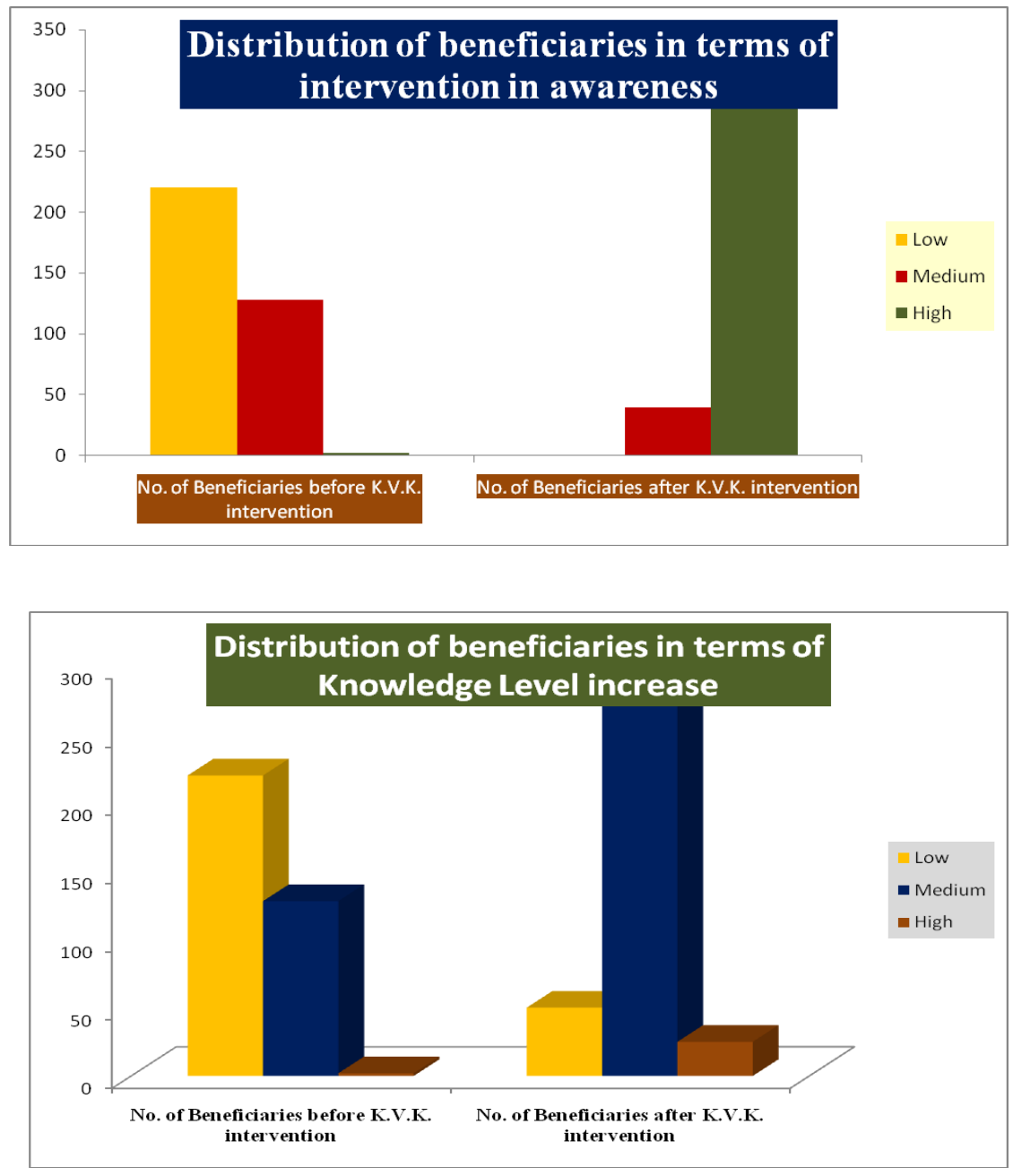


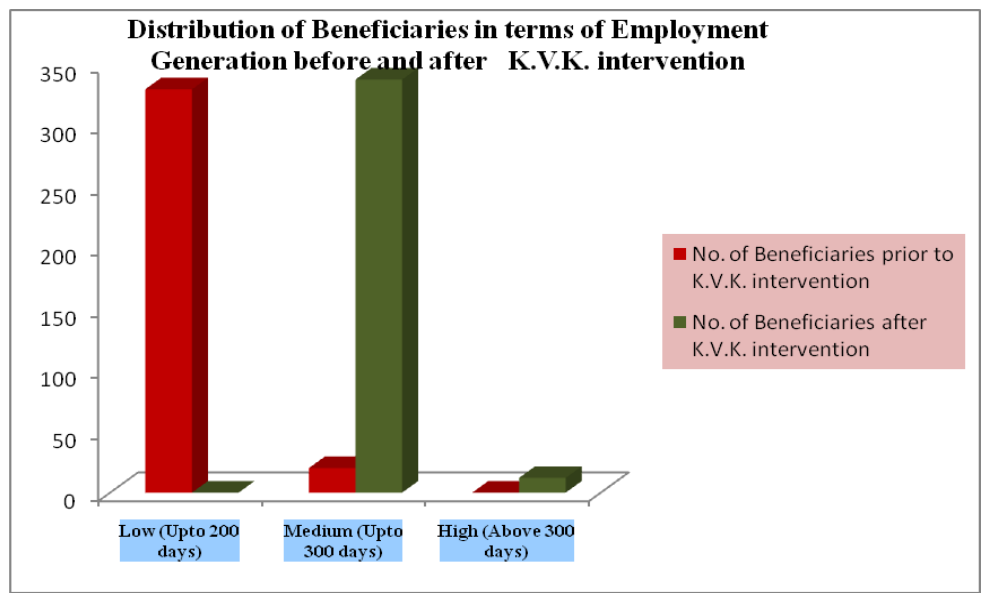

Data in Table 4 indicate the employment/engagement in terms of day's in the year, under three groups low, medium and high.

Data reveals that $94.28 \%$ of the people could obtain upto 200 days of and $5.71 \%$ could obtain employment upto 300 days. None of the beneficiaries could have employment above 300 days. After the intervention of K.V.K. $96.57 \%$ of tribals could obtain employment upto 300 days and 3.42 had employment above 300 days. Thus it is concluded that the majority of the respondent were engaged for more that 200 days, which indirectly reduced drudgery and destruction of forest based things (hunting and wood cutting).

The result revealed from the data in Table 5 indicate that $68.57 \%$ of the tribals had income upto 'Rs. 14000.00', 26\% had income upto Rs. 12000.00 and $4.57 \%$ had income above Rs. 14000.00. It is point to be noted that this group had better cultivable land prior to intervention by K.V.K.

A tremendous change in the hike of financial status was observed $74 \%$ of tribals could reach the higher income level i.e. above 14000/-, 23.14 had income upto 14000/- and only $2.85 \%$ of the tribals remained at the lower level of income upto 12000/- however on an average the deficit in the budget could be overcome by the K.V.K. intervention despite of adverse climate conditions scanty rains and $(950 \mathrm{~mm}$ against $1350 \mathrm{~mm})$ extreme cold, horizontal and vertical frost which has effected even wheat (Table 7).

Sujata is a rainfed wheat it observed maximum yield $15 \mathrm{q} / \mathrm{ha}$, average of 10.40 $\mathrm{q} / \mathrm{ha}$ and a few patches where wheat was grown got average yield of $4.2 \mathrm{q} / \mathrm{ha}$ which was $147 \%$ increase.

The B.C. Ratio in the case of local check was observed to be 1.27 and that of demonstration $1.86 \%$.

Since the area was mostly single cropped, the demonstration increased cropping intensity to $150 \%$. The average net returns cover the deficit of 4500.00 computed during pre survey. Hence Rs. 2240.00 will remain with him as saving and thus his livelihood has been recurred.

In conclusion, seed is a major factor on which the total agriculture scenario depends and unfortunately this has been a great problem. The present project will proof to be a land 
mark in the stream lining of primitive tribe Baiga community. The project not only helped in over coming the deficit but also increased level of knowledge and awareness about the improved production technologies in which seed itself plays a very important role.

Maximum area in the Baiga belt was monocropped except a few patches of unorganized Rabi cultivations. The present programme not only increased income and employment but also imparted knowledge and created awareness for improved technologies.

The programme will bring down change in life style of Baiga community feeding habit in specific. Tribals were delighted to have wheat in food they said poorer has not remained a dream now. Efforts of JNKVV will definitely play an important role in development of Baiga Community and help them to join in the main stream very soon.

\section{References}

Bhuyan, R.K., N. Bordoloi and A.K.Singh (1995) Awareness of farmers towards agricultural programmes. Journal of the Agricultural Science, 8(2).

Government of India (1984) Planning Commission , Report of the Working Group on District Planning, vol I, May, New Delhi.

https://www.researchgate.net/publication/242 132190_Health_and_Nutrition_Profile_ of_Tribals_of_Madhya_Pradesh_and_C hhattisgarh

\section{How to cite this article:}

Geeta Singh, Harish Dixit and Yadav, K.S. 2019. Ensuring Livelihood of Baiga Tribes through Quality Seed Production Programme. Int.J.Curr.Microbiol.App.Sci. 8(07): 1612-1619. doi: https://doi.org/10.20546/ijcmas.2019.807.192 